$\begin{array}{rr}\text { FIT(1)PATOLOGI } & \text { Volume } 10, \text { Nomor 5, Oktober } 2014 \\ \text { IN D ONESIA } & \text { Halaman } 139-144 \\ \text { ISSN: } 0215-7950 & \text { DOI: } 10.14692 / \text { jif. } 10.5 .139\end{array}$

\title{
Pengendalian Penyakit Busuk Buah Phytophthora pada Kakao dengan Cendawan Endofit Trichoderma asperellum
}

\author{
Control of Phytophthora Pod Rot Disease on Cacao using \\ Endophytic Fungi Trichoderma asperellum
}

\author{
Andi Akbar Hakkar, Ade Rosmana*, Muhammad Danial Rahim \\ Universitas Hasanuddin, Makassar 90245
}

\begin{abstract}
ABSTRAK
Busuk buah Phytophthora (BBP) yang disebabkan Phytophthora palmivora merupakan salah satu penyakit penting yang berperan dalam penurunan produksi kakao. Penggunaan cendawan endofit Trichoderma dilakukan untuk mengendalikan penyakit ini. Laju insidensi penyakit BBP selama 12 minggu setelah 3 kali aplikasi penyemprotan susupensi Trichoderma asperellum ART-4/G.J.S 091559 pada konsentrasi $1 \mathrm{~g} \mathrm{~L}^{-1}, 2 \mathrm{~g} \mathrm{~L}^{-1}$, dan $4 \mathrm{~g} \mathrm{~L}^{-1}$ berturut-turut ialah 5.4, 5.3, dan 3.7\% per minggu; sedangkan pada kontrol mencapai $8.4 \%$ per minggu. Buah di lapangan yang tampak sehat dan telah diberi perlakuan $T$. asperellum dengan konsentrasi 2 dan $4 \mathrm{~g} \mathrm{~L}^{-1}$ tidak memperlihatkan gejala BBP setelah inkubasi di laboratorium selama 1 minggu, sedangkan pada kontrol hampir seluruh permukaan buahnya membusuk. T. asperellum dapat direisolasi dari jaringan buah 12 minggu setelah penyemprotan terakhir. Penelitian ini menunjukkan potensi penggunaan T. asperellum sebagai agens pengendali biologi P. palmivora.
\end{abstract}

Kata kunci : agens hayati, busuk buah kakao, Phytophthora palmivora

\section{ABSTRACT}

The Phytophthora pod rot (PPR) caused by Phytophthora palmivora is one of important diseases affecting the decrease of cacao productivity. The use of endophytic Trichoderma have a big potential for controlling this disease. The rate of PPR incidence in twelve weeks after three times application by spraying of ART-4/G.J.S 09-1559 isolate of Trichoderma asperellum with concentration of $1 \mathrm{~g} \mathrm{~L}^{-1}, 2 \mathrm{~g}$ $\mathrm{L}^{-1}, 4 \mathrm{~g} \mathrm{~L}^{-1}$ was $5.4 \%, 5.3 \%$, and $3.7 \%$, respectively per week; while the rate of PPR incidence on control was $8.4 \%$ per week. Apparently healthy pods pretreated with above concentrations of $T$. asperellum in field showed 30, 0 , and $0 \%$ infested by PPR on its surface, respectively after one week incubation in laboratory, compared to a $90 \%$ of surface infestation by PPR on control. After 12 week of inoculation, $T$. asperellum was recovered from pod tissue. This data demonstrated the potential of T. asperellum as bio control agent of PPR disease on cacao.

Key words: bio control agent, Phytophthora palmivora, pod rot disease

*Alamat penulis korespondensi: Fakultas Pertanian Universitas Hasanuddin Tamalanrea Jalan Perintis Kemerdekaan KM. 10, Makassar 90245

Tel: 0411-586477, Faks: 0411-586477; Surel: a2rosmana@yahoo.com 


\section{PENDAHULUAN}

Penyakit busuk buah Phytophthora (BBP) merupakan salah satu penyakit utama yang dapat mempengaruhi sistim produksi kakao di dunia. Penyakit ini dapat menyebabkan kehilangan hasil mencapai $90 \%$ terutama pada musim hujan atau musim kemarau pada lahan dengan populasi semut yang banyak (Rosmana et al. 2010a). Di Indonesia $P$. palmivora merupakan spesies utama yang menyerang semua fase perkembangan buah kakao sehingga selain menyebabkan busuk buah, juga menyebabkan layu cherelle (Acebo- Guerrero et al. 2012)

Salah satu teknik yang berpotensi dikembangkan untuk mengendalikan penyakit ini ialah penggunaan cendawan Trichoderma. Kemampuan pengendalian biologi sejumlah spesies Trichoderma telah dilaporkan. Penggunaan Trichoderma nonendofit isolat Sulawesi dapat menurunkan insidensi penyakit BBP hampir sama dengan penggunaan fungisida sintetik (Rosmana et al. 2006). Potensi pengendalian $P$. palmivora dengan Trichoderma juga telah diteliti di beberapa negara dan memberikan hasil yang menjanjikan (Hanada et al. 2009).

Rosmana et al. (2014) mengidentifikasi sejumlah Trichoderma asperellum endofit dari buah di pertanaman kakao di Sulawesi dan dua isolat di antaranya telah diujicobakan pada penyakit hawar daun Phytophthora yang disebabkan P. palmivora di pembibitan kakao melalui aplikasi pada akar. Uji coba tersebut menunjukkan potensi $T$. asperellum dalam menurunkan penyakit (Azis et al. 2014). Potensi T. asperellum untuk mengendalikan penyakit BBP di lapangan dievaluasi lebih lanjut pada musim hujan. Kemampuan cendawan endofit tersebut untuk penetrasi pada buah dan berperan menginduksi ketahanan diamati pula.

\section{BAHAN DAN METODE}

\section{Perbanyakan $T$. asperellum}

Trichoderma asperellum yang digunakan ialah isolat ART-4/G.J.S. 09-1559 koleksi
Dr Ade Rosmana. Isolat ini ditumbuhkan pada medium agar-agar kentang dekstrosa (ADK), kemudian diperbanyak pada medium beras dalam kantong plastik. Kultur yang telah berumur kurang lebih satu minggu, selanjutnya diformulasi dalam bentuk tepung sehingga formula ini selain mengandung spora juga memiliki miselium.

\section{Aplikasi T. asperellum di Lapangan}

Pengujian di lapangan disusun dalam rancangan acak kelompok dengan 4 perlakuan dan masing masing perlakuan diulang 3 kali. Perlakuan terdiri atas konsentrasi T. asperellum, yaitu $1 \mathrm{~g} \mathrm{~L}^{-1}, 2 \mathrm{~g} \mathrm{~L}^{-1}, 4 \mathrm{~g} \mathrm{~L}^{-1}$, dan sebagai pembanding tanpa T. asperellum. Pada masingmasing petak perlakuan terdapat 16 pohon kakao sehingga total pohon pada percobaan ialah 192 pohon. Dari jumlah pohon ini dipilih buah kakao berukuran panjang di bawah $10 \mathrm{~cm}$ sebanyak 600 buah kakao atau 50 buah per petak. Aplikasi T. asperellum pada buah dilakukan dengan 3 kali penyemprotan pada pagi hari dengan interval waktu penyemprotan setiap 7 hari. Suspensi yang disemprotkan merupakan campuran $T$. asperellum, air, dan carboxy methyl cellulose $0.7 \%$.

\section{Pengamatan Insidensi Penyakit Busuk Buah Phytophthora dan Keberadaan T. asperellum dalam Buah}

Pengamatan terhadap insidensi penyakit BBP dilakukan selama 12 minggu dengan interval 1 minggu. Insidensi penyakit dihitung dengan rumus

$$
\mathrm{IP}=\mathrm{a} / \mathrm{b} \times 100 \%, \text { dengan }
$$

IP, insidensi penyakit BBP; a, jumlah buah yang terserang penyakit BBP; b, jumlah seluruh buah yang diamati.

Keberadaan T. asperellum dalam jaringan buah kakao diamati setelah buah dibilas dengan alkohol $70 \%$ dan dibiarkan selama 1-2 menit, kemudian dicuci berulang dengan menggunakan akuades steril. Kulit kakao dilepas dengan pisau steril, sampel jaringan buah yang terdiri atas plasenta dan potongan biji diambil dan diinokulasikan pada medium ADK. Deteksi keberadaan T. asperellum 
juga dilakukan secara langsung dengan mengamati jaringan kulit bagian dalam buah yang diwarnai dengan lactophenol blue menggunakan mikroskop.

Sebanyak 2 buah kakao yang tampak sehat di lapangan diambil dari tanaman yang telah diberi perlakuan T. asperellum dan kontrol, kemudian diinkubasikan selama 1 minggu di laboratorium pada kondisi lembab. Hal ini dilakukan untuk melihat ketahanan buah pasca panen terhadap infeksi $P$. palmivora yang terbawa dari lapangan.

Untuk melihat lamanya $T$. asperellum bertahan pada tanaman kakao yang sudah diberi perlakuan, maka setelah 6 bulan pengujian berakhir sampel buah diambil dan dibawa ke laboratorium. Pengamatan dilakukan dengan metode yang sama seperti diuraikan sebelumnya.
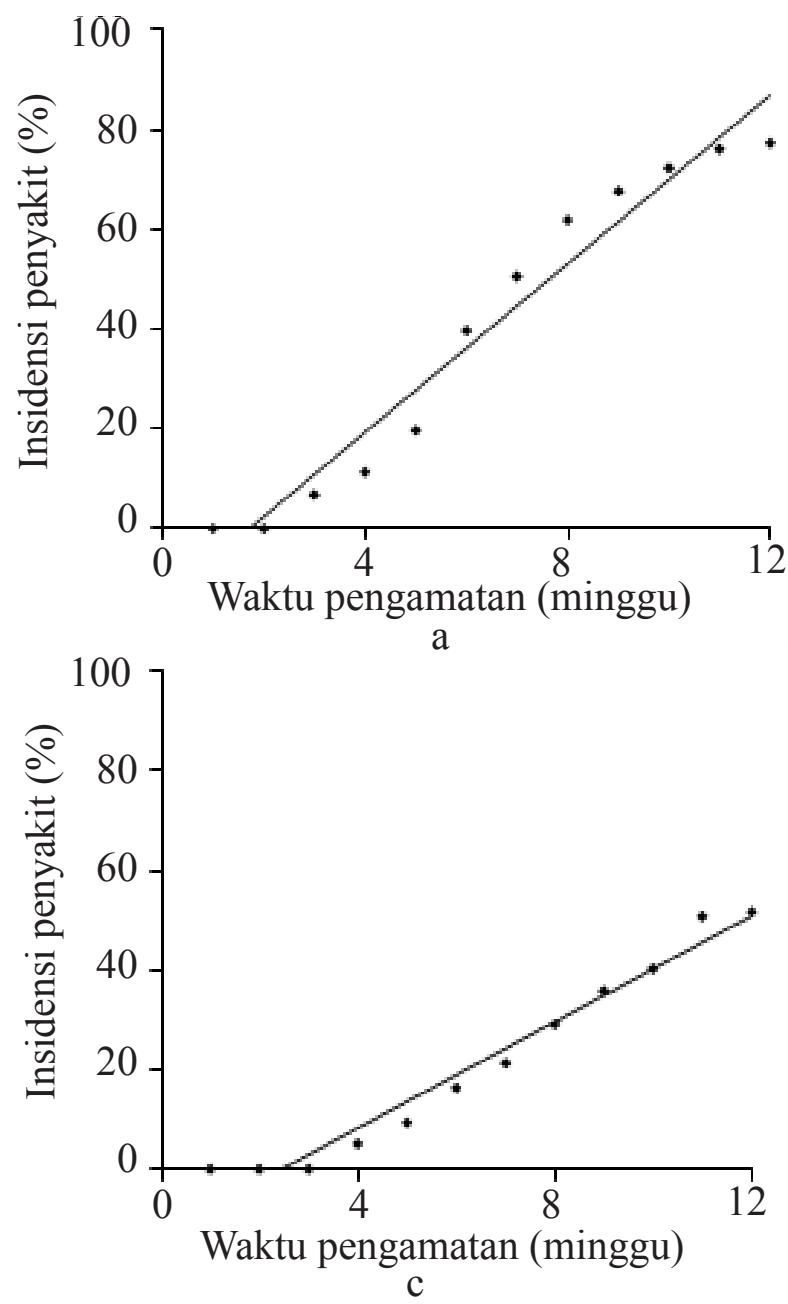

\section{Analisis Data}

Laju perkembangan penyakit BBP pada setiap perlakuan dianalisis dengan persamaan regresi berdasarkan insidensi penyakit dan waktu pengamatan. Analisis dengan uji $\mathrm{T}$ dilakukan untuk mengevaluasi perbedaan antara koefisien regresi.

\section{HASIL}

Penyakit BBP mulai muncul pada minggu ke-3 pada perlakuan kontrol, sedangkan pada petak yang diberi perlakuan $T$. asperellum penyakit BBP muncul pada minggu ke-4. Laju perkembangan penyakit selama 12 minggu pada petak kontrol dan petak perlakuan $T$. asperellum $1 \mathrm{~g} \mathrm{~L}^{-1}, 2 \mathrm{~g} \mathrm{~L}^{-1}, 4 \mathrm{~g} \mathrm{~L}^{-1}$ berturutturut ialah 8.4, 5.4, 5.3, dan 3.7\% (Gambar 1). Laju perkembangan penyakit pada perlakuan
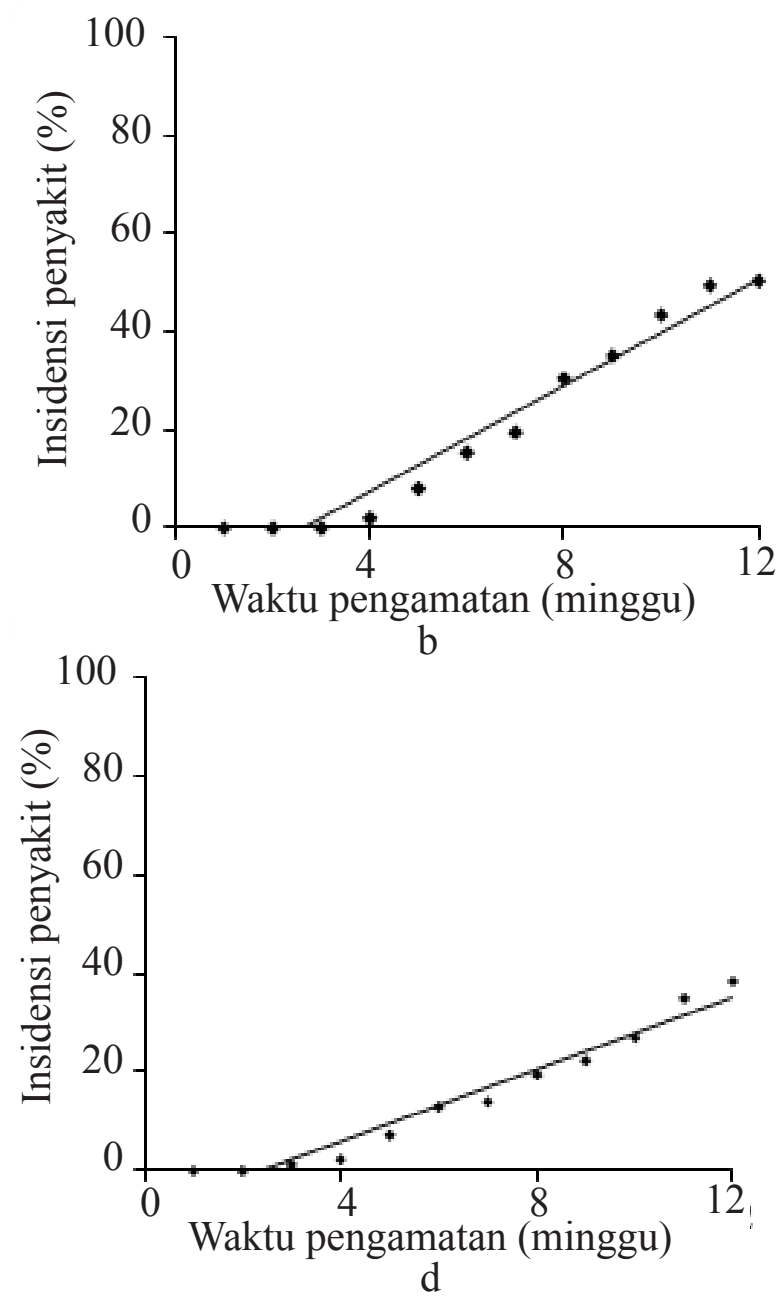

Gambar 1 Insidensi penyakit busuk buah Phytophthora (BBP) setelah 3 kali aplikasi penyemprotan Trichoderma asperellum ART-4/G.J.S. 09-1559 pada konsentrasi. a, kontrol; b, $1 \mathrm{~g} \mathrm{~L}^{-1}$; c, $2 \mathrm{~g} \mathrm{~L}^{-1}$; dan d, $4 \mathrm{~g} \mathrm{~L}^{-1}$. 
kontrol berbeda nyata dengan perlakuan $T$. asperellum $1 \mathrm{~g} \mathrm{~L}^{-1}, 2 \mathrm{~g} \mathrm{~L}^{-1}, 4 \mathrm{~g} \mathrm{~L}^{-1}$, sedangkan antara perlakuan $T$. asperellum tidak berbeda nyata $(\mathrm{P} \leq 0.05)$.

T. asperellum berhasil direisolasi dari $25 \%$ sampel biji dan plasenta 12 minggu setelah aplikasi T. asperellum, tetapi tidak ditemukan pada perlakuan kontrol. Hasil inkubasi buah yang tampak sehat dari lapangan dan tidak diberi perlakuan $T$. asperellum menunjukkan bahwa gejala busuk buah tampak menutupi seluruh permukaan buah. Sebaliknya, gejala busuk buah hanya menutupi 30\% permukaan buah pada perlakuan $1 \mathrm{~g} \mathrm{~L}^{-1} T$. asperellum. Gejala busuk sama sekali tidak tampak pada permukaan buah kakao pada perlakuan $2 \mathrm{~g} \mathrm{~L}^{-1}$ dan $4 \mathrm{~g} \mathrm{~L} \mathrm{~L}^{-1}$ T. asperellum (Gambar 2). Pengamatan 6 bulan setelah panen terakhir menunjukkan hanya 1 dari 12 buah yang diamati mengandung $T$. asperellum.

\section{PEMBAHASAN}

Penelitian terdahulu menggunakan $T$. asperellum ART-4/G.J.S.09-1559 menunjukkan bahwa cendawan ini dapat mengolonisasi batang dan daun kakao melalui aplikasi akar dan sambungan pucuk (Aziz et al. 2014; Rosmana et al. 2014). Pada penelitian ini ditunjukkan pula bahwa isolat yang sama dapat mengolonisasi buah setelah aplikasi melalui permukaan buah kakao dan keberadaannya dalam buah relatif lama sampai buah dipanen. Belum ada informasi tentang mekanisme penetrasi Trichoderma pada buah kakao. Bailey et al. (2008) mengamati adanya kolonisasi trikoma batang oleh Trichoderma

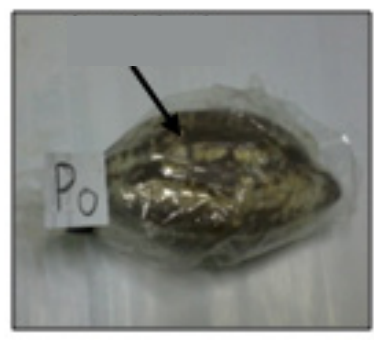

a

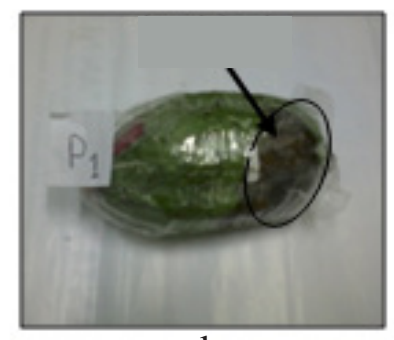

b

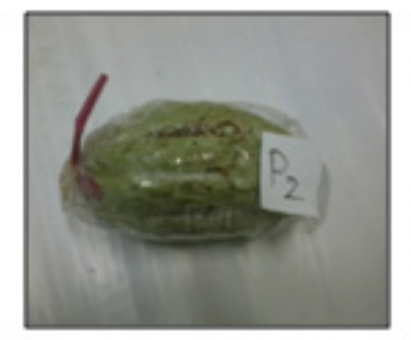

C dan hifanya keluar dari ujung trikoma setelah inokulasi bibit kakao melalui akar (Ishida et al. 2008). Buah kakao terutama buah muda memiliki banyak trikoma (Susilo et al. 2009) dan ujung trikoma yang merupakan tempat eksresi eksudat mungkin menjadi tempat masuk Trichoderma yang disemprotkan pada permukaan buah. Diketahui bahwa Trichoderma dapat menembus secara langsung pada rambut akar (Yedida 2000).

Penurunan insidensi penyakit BBP secara progresif berdasarkan konsentrasi T. asperellum yang diaplikasikan berhubungan dengan besarnya kesempatan inokulum awal untuk menembus dan mengolonisasi buah kakao sehingga memberikan proteksi yang lebih besar. Mekanisme Trichoderma menghambat patogen Phytophthora spp. ialah melalui cara langsung, yaitu dengan mikoparasitisme atau antibiosis (Bailey et al. 2008; Bae et al. 2011; Atanasova et al. 2013). Namun, penelitian ini menunjukkan bahwa buah kakao yang tampak sehat di lapangan sudah terinfeksi oleh BBP. Semakin tinggi konsentrasi $T$. asperellum yang diaplikasikan akan memberikan perlindungan semakin besar terhadap terjadinya busuk buah. Hasil yang sama dilaporkan juga oleh Rosmana (2013, tidak dipublikasikan). Hal ini memberikan hipotesis adanya mekanisme tidak langsung yang diberikan oleh $T$. asperellum untuk pertahanan buah terhadap $P$. palmivora yang terbawa buah dari lapangan. Sejumlah galur Trichoderma di antaranya DIS 70a, DIS 219b, DIS 219f, dan DIS 172ai telah dipelajari secara detail untuk asosiasi endofitiknya dengan jaringan kakao di atas

Gambar 2 Gejala busuk buah Phytophthora yang muncul setelah inkubasi selama 1 minggu di laboratorium. a, busuk buah pada kontrol; b, busuk buah pada perlakuan $1 \mathrm{~g} \mathrm{~L}^{-1}$ Trichoderma asperellum; c, perlakuan $2 \mathrm{~g} \mathrm{~L}^{-1}$ T. asperellum; d, perlakuan $4 \mathrm{~g} \mathrm{~L}^{-1}$ T. asperellum. 
tanah serta kemampuannya untuk mengubah ekspresi gen kakao selama kolonisasinya (Bailey et al. 2006; Bailey et al. 2008). Bae et al. (2011) menunjukkan bahwa kolonisasi cendawan endofit kakao T. stilbohypoxyli pada tanaman cabai menginduksi pengenal yang berhubungan dengan pertahanan seperti protein lipid transferase. Gen yang ikut serta dalam respons hipersensitif, biosintesis fitoaleksin seskuiterpen, serta gen yang berperan dalam metabolisme hormon, seperti etilena, asam salisilat, asam jasmonat dan asam giberelat juga diinduksi.

Aplikasi T. asperellum pada konsentrasi 4 $\mathrm{g} \mathrm{L}^{-1}$ dapat menghambat kemunculan penyakit BBPsekitar 50\% di musim hujan. Hasil proteksi yang sama diperoleh dengan penggunaan pestisida kimiawi sintetis yang diaplikasikan berulang dengan interval satu minggu selama kurang lebih 3-4 bulan oleh petani kakao. Setelah enam bulan aplikasi, sejumlah buah terdeteksi mengandung $T$. asperellum yang sama. Hal ini merupakan bukti pertama yang menunjukkan bahwa $T$. asperellum dapat bertahan lama pada pertanaman kakao.

\section{UCAPAN TERIMA KASIH}

Penulis mengucapkan terima kasih kepada Australian Center for International Agricultural Research (ACIAR) yang telah membiayai penelitian ini melalui proyek Hort2010/011.

\section{DAFTAR PUSTAKA}

Acebo-Guerrero Y, Hernandez-Rodriguez A, Heydrich-Perez M, El Jaziri M, HernandezLauzardo AN. 2012. Management of black pod rot in cacao (Theobroma cacao L.): a review. Fruits. 67:41-48. DOI: http:// dx.doi.org/10.1051/fruits/2011065.

Atanasova L, Le Crom S, Gruber S, Coulpier F, Seidl-Seiboth V, Kubicek CP, Druzhinina IS. 2013. Comparative transcriptomics reveals different strategies of Trichoderma mycoparasitism. BMC Genomics. 14:121. DOI: http://dx.doi.org/10.1186/1471-216414-121.
Aziz AI, Rosmana A, Dewi VS. 2014. Pengendalian penyakit hawar daun phytophthora pada bibit kakao dengan Trichoderma asperellum. J Fitopatol Indones. 9:15-20. DOI: http://dx.doi. org/10.14692/jfi.9.1.15.

Bae H, Roberts DP, Lim HS, Strem MD, Park SC, Ryu CM, Melnick RL, Bailey BA. 2011. Endophytic Trichoderma isolates from tropical environments delay disease onset and induce resistance against Phytophthora capsici in hot pepper using multiple mechanisms. Mol Plant Microb In. 24:336-351. DOI: http://dx.doi. org/10.1094/MPMI-09-10-0221.

Bailey BA, Bae H, Strem MD, Roberts DP, Thomas SE, Crozier J, Samuels GJ, Choi I-Y, Holmes KA, 2006. Fungal and plant gene expression during the colonization of cacao seedlings by endophytic isolates of four Trichoderma species. Planta. 224:1449-1464. DOI: http://dx.doi. org/10.1007/s00425-006-0314-0.

Bailey BA, Bae H, Strem MD, Crozier J, Thomas SE, Samuels GJ, Vinyard BT, Holmes KA. 2008. Antibiosis, mycoparasitism, and colonization success for endophytic Trichoderma isolates with biological control potential in Theobroma cacao. Biol Control. 46:24-35. DOI: http://dx.doi.org/10.1016/j. biocontrol.2008.01.003.

Hanada RE, Pomella AWV, Soberanis W, Leandro L, Loguercio LL, Pereira JO. 2009. Biocontrol potential of Trichoderma martiale against the black-pod disease (Phytophthora palmivora) of cacao. Biol Control. 50:143-149. DOI: http://dx.doi. org/10.1016/j.biocontrol.2009.04.005.

Ishida $\mathrm{T}$, Kurata $\mathrm{T}$, Okada $\mathrm{K}$, Wada $\mathrm{T}$. 2008. A genetic regulatory network in the development of trichomes and root hairs. Annu Rev Plant Biol. 59:365-386. DOI: http://dx.doi.org/10.1146/annurev. arplant.59.032607.092949.

Rosmana A, Sahrani E, Saharuddin W, Junaid M. 2006. Komparasi penggunaan Trichoderma dengan fungisida sintetik untuk mengendalikan penyakit busuk 
buah phytophthora kakao. Fitomedika. 6:22-25.

Rosmana A, Samuels GJ, Ismaiel A, Ibrahim ES, Chaverri P, Herawati Y, Asman, A. 2014. Trichoderma asperellum, a dominant endophyte species in cacao grown in Sulawesi with potential for controlling vascular streak dieback disease. Trop Plant Pathol. (in press).

Rosmana A, Shepard M, Hebbar P, Mustari A. 2010b. Control of cocoa pod borer and phytophthora pod rot using degradable plastic pod sleeves and a nematode Steinernema carpocapsae. Indon J Agric Sci. 11:41-47.

Rosmana A, Waniada C, Junaid M, Gassa A. 2010a. Peranan semut Iridomirmex cordatus (Hyminoptera: Formicidae) dalam menularkan patogen busuk buah Phytophthora palmivora. Pelita Perkebunan. 26:169-176.

Susilo AW, Mangoendidjojo W, Witjaksono, Mawardi S. 2009. Pengaruh perkembangan umur buah beberapa klon kakao terhadap keragaan sifat ketahanan hama penggerek buah kakao. Pelita Perkebunan. 25:1-11.

Yedidia I, Benhamou N, Kapulnik Y, Chet I, 2000. Induction and accumulation of PR protein activity during early stages of root colonization by the mycoparasite Trichoderma harzianum strain T-203. Plant Physiol Bioch. 38:863-873. DOI: $\quad$ http://dx.doi.org/10.1016/S09819428(00)01198-0. 